\title{
Supervision of Participatory Training on Nonformal Education Model
}

\author{
Abdul Rahmat ${ }^{\mathrm{a}}$, Halim K. Malik ${ }^{\mathrm{b}}$ \\ Nonformal Education, Gorontalo State University \\ Gorontalo, Indonesia \\ Corresponding e-mail: aabdulrahmat@ung.ac.id, ${ }^{b}$ halimmalik@yahoo.com
}

\begin{abstract}
This study begins with some weaknesses that are generally experienced in the conduct of training that is not based on competency measurement so that the materials given are not suitable to the needs of the trainees. The approach of this research is to use qualitative-analysis research. Procedures used in data collection; observation, interview and documentation. To ensure the validity of data, in this study triangulation. The analysis used is qualitative-interactive analysis, which consists of three flow of activities that run simultaneously, namely; Data reduction, data presentation, and conclusions. The results showed that to improve the performance of the guardian, the supervision of technical training with the Participatory Training Model begins with the analysis, which is the needs analysis of the things that will become the object of training, then proceed with the design of the training program, that is the step of designing the training programs. The next stage is the implementation and implementation, namely the implementation process and Implementation of training programs. Then it ends with an evaluation that is the stage to provide assessment and development analysis.
\end{abstract}

Keywords: training, quality and participatory training model

\section{INTRODUCTION}

The Learning Activity Center of Gorontalo Province as an institution for the implementation of Off-School Education is established based on Gorontalo Governor Decree number 196 of 2001 dated July 21, 2001. The main task of BPKB Gorontalo Province is to develop the model of guidance and testing of the education program outside school. Researching, testing, developing the Nonformal education program model, implementing learning, education and training and improving the skill of Nonformal education personnel. Implement supervision, monitoring, evaluation, analysis and reporting activities and implementing agencies diklusepora in the region of Gorontalo province. In order to support the above office hall, it needs to be supported by human resources and other supporting facilities and infrastructures consisting of 3 structural personnel, 19 students and 24 administrative staff. Performance is very important for every organization. Therefore, to achieve these strategic goals, the ability to properly manage the performance of its officials is needed. (Muenjohn, Nuttawuth and Anona Armstrong, 2007). Employee performance is as a function (f) of the interaction of ability (A), and motivation $(M)$, that is, performance $=f(A \times M)$. If either is inadequate, performance will be negatively affected. (Robbins, 2005:192). An individual's intelligence and skills (subsumed under the label ability) must be considered in addition to motivation if we are to be able to accurately explain and predict employee performance. (Phinney, J. S., Cantu, C. L., \& Kurtz, D. A. 1997). We need to add opportunity to perform $(\mathrm{O})$ to our equation : performance $=\mathrm{f}(\mathrm{A} \mathrm{x}$ $\mathrm{M} \times \mathrm{O})$. Even though an individual may be willing and able, there may be obstacles that constrain performance (Muenjohn, Nuttawuth dan Anona Armstrong., (2007). Training for the guardian of learning is always done every year and getting better from the side of the type of personnel trained or in terms of quantity or number of participants. Unfortunately, the training has not been able to provide concrete answers to the problem of poor quality of non-formal education. Abdul Rahmat and Christina Catur Widayati (2016).

Initial observation there are some weaknesses that are generally experienced by the organizer of the training. The weaknesses are: (1) the organizer has not implemented correct training management, (2) the training is held not based on the competency measurement so that the material given does not match the needs of the trainee, (3) The more training is run the guidance provisions Existing operations on the project and other issues. This condition resulted in budget efficiency as well as in effectiveness on other aspects. On the basis of these competencies, the training is designed by formulating competencies, competency measurement, comptability measurement analysis, curriculum development, and determining training materials and determining 
various other training attributes. Phinney, J. S., Cantu, C. L., \& Kurtz, D. A., (1997).

A training model is considered effective when it can be based on curriculum, approaches and strategies that match the learning needs of the target students and the problems that occur in the middle of it. This requires special requirements in building an effective and efficient training model. These requirements include the learning needs of trainees (target students, residents of learning etc.). The term in the world of education outside school is known as TNA (Training Needs Assessment), SMA (Subject Matter Analysis) and ATD (Approaches to Training and Development). (Allison Rossett and Joseph W.Arwady, 1987).

Participatory Training Model (Participatory Training Model). This exercise model includes 10 steps of sequential activity that can be described as follows. Yueh-Shian Lee and Weng-Kun Liu, (2012) this training model is actually a renewal (innovation) of the models that have been described earlier. The participatory learning model actually emphasizes the learning process, where the learning activities in the training are built on the active participation of the trainees in all aspects of the training activities, from planning, implementing, to assessing the learning activities in the training. The efforts undertaken by the trainers in principle are more emphasized on motivation and involve the participants' activities. Drucker (1977: 237-242)

Ruky (2001: 2) states that the meaning of performance or performance is the result of work that can be achieved by a person or group of people within an organization, in accordance with the authority and responsibility of each, in order to achieve the objectives of the organization concerned legally, And in accordance with morals and ethics.

The above opinion is illustrated by Robbins (2005: 192) as follows:

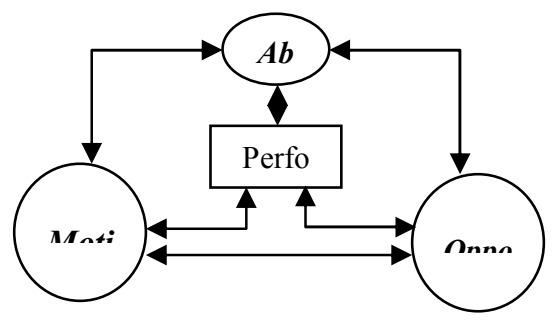

Figure 1. Performance Dimensions Image

In line with the above quotes, Merzuki, Siti Emalia and A. Latif, Hamrila. (2014) states that, performance is a person's willingness to do something activity and refine it in accordance with his responsibility for the expected results. If it is associated with performance as a noun, in which one of its entries is the result of something done, the notion of performance or performance is the work achieved by a person or group of persons within an organization in accordance with the authority and responsibility Respectively, in an effort to achieve the objectives of the organization legally, not to violate the law and not to contradict morals and ethics. (Luanglath, Inpong. (2014). The phenomenon in the field is still found the performance of the less optimum pamong because of the low commitment. Low commitment can be caused by "dominant guidance of supervisor". Pamong just as pamong that lack / no role in determining the policy. In the managerial order, pamong is in a pattern that makes the pamong in a position that is not very supportive for the realization of its professional performance. Pamong is more often treated as an object and subordinate, who are in a position and conditioned by rigid bureaucratic management patterns, and in supervision that is sometimes contrary to the demands of professional and pedagogical performance. Pamong is in a depressed situation, passive, reactive, and a weak person is helpless, so lack of confidence and not authoritative. Possible consequences are the pamong difficult to achieve professional performance as idealized.

Another phenomenon encountered, ie commitments agreed upon at the time of planning, was not implemented. Influence caused is mismatch between planning and execution, which result to the quality of performance pamong become down. In addition, in the field also occurs, that the sourcecontrol pamong urged by the necessity of life. Pamong's income is relatively small compared to employees in the company. In the face of such circumstances, the source of control often becomes unstable to commit acts that deviate from the rules and responsibilities of the civil service.

\section{RESEARCH METHODOLOGY}

This research was conducted at the Learning Activity Center of Gorontalo Province conducted from March to June 2016. The approach of this research is to use qualitative-analysis research. Qualitative research is a fact-finding with the right interpretation with the aim to make a systematic, factual, accurate, factual, accurate study of the facts, traits and relationships between the phenomena being investigated. (Bogdan and Biklen (1982: 88). Sources of research data are classified into three kinds, namely data sources of people, data sources of places or objects, and data sources in the form of symbols. (Miles and Huberman (1992: 7) Procedures used in data collection, observation, interviews and documentation. To ensure the validity of data, in this study triangulation, the technique of examining the data by utilizing something else outside the data for checking purposes or as a comparison data. In this study, researchers used triangulation to obtain the truth of the research findings. The analysis used is qualitative-interactive analysis, which consists of three flow of activities that run simultaneously, 
namely; Data reduction, data presentation, and conclusions.

\section{RESULTS AND DISCUSSION}

\subsection{Development of Training Program}

In the Participatory Training Model, the development of training programs, for training to be useful and profitable requires a systematic stages or steps. In general, there are three stages in the training namely the needs assessment stage, the implementation stage of training and evaluation phase. Or with other terms there are phases of training planning, training implementation phase and post-training phase.

The content of the program is the embodiment of the assessment of needs and materials or materials to achieve the training objectives. The content of this program contains the skills (skills), knowledge and attitudes that are a learning experience in training that is expected to create behavioral changes. Learning experiences and or materials on the training should be relevant to the needs of the participants and workplace institutions. The principles of effective learning principles are those that have a match between the method and the learning style of the trainee and the types of pamongan, which require. Basically the principles of learning worthy of being considered for implementation range from five things: participation, reputation, relevance, diversion, and feedback (Sondang P. Siagian, 1994: 190).

The implementation of the program of training in principle is very situational in nature. This means that with the emphasis on calculating the needs of organizations and trainees, the use of learning principles can vary in intensity, so as to reflect on the use of certain approaches, methods and techniques in the implementation of the training process. Skill, knowledge, and skill of knowledge ability of workers as a trainee is a learning experience of a training program followed. Training is said to be effective, if the training results are in accordance with the duties of the trainees. And useful on the task of pamongan. And the last step of the development of training program is the evaluation (evaluation) of training Implementation of training program is said to succeed if in the trainee happens a process of transformation of learning experience.

\subsection{Training Mechanism}

The training mechanism here means the method or method used in a training activity. So analogue training mechanisms and closer to the approach or methods and training techniques. In the organization of training, none of the best training methods and techniques. It all depends on the situation of the conditions of need. Whether or not the training technique is used depends on considerations such as financial savings, program materials, the availability of particular facilities, the preferences and competencies of the participants, the preference of the trainer's abilities and the principles of learning to be applied. However, training managers should recognize and understand all training methods and techniques, so they can choose and determine which methods and techniques are best used in accordance with their needs, circumstances and conditions.

\subsection{Training Effectiveness}

The absence of a definitive definition of effectiveness is because everyone gives different meanings. Different formulas are caused because the meaning of effectiveness depends on the angle by which the experts define it. View. These different experts have a similarity, which defines effectiveness as meaning to the ability to achieve a predetermined goal or goal. Effectiveness is seen in three perspectives, according to Gibson (1988: 28), as follows: (1) effectiveness from an individual perspective; (2) effectiveness from a group perspective; And (3) effectiveness from an organizational perspective. This implies that effectiveness has three levels which are a complementary one. Where the effectiveness of individual perspectives is at an early stage for effective group or effective organization.

From some sense above the effectiveness of meaning-oriented to the outcome and also processoriented to tap:

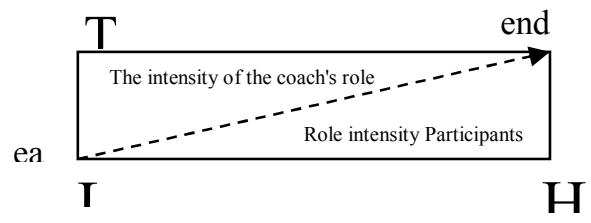

Deskriftion : $\mathrm{H}=$

Based on the picture above it can be seen that at the beginning of training activities the intensity of the role of trainers is high: This role is shown in helping participants by presenting information about teaching materials (exercise material) and by doing motivation and guidance to participants. The intensity of the activities of the trainers (the source) is declining further so that the role is directed to monitor and provide feedback on training activities and on the contrary the participants' activities at the beginning of the activity are low, these initial activities are used only to receive training materials, information, guidance, materials, Steps of activities etc. Then citizen participation grew higher and higher and actively build a more meaningful training atmosphere. 


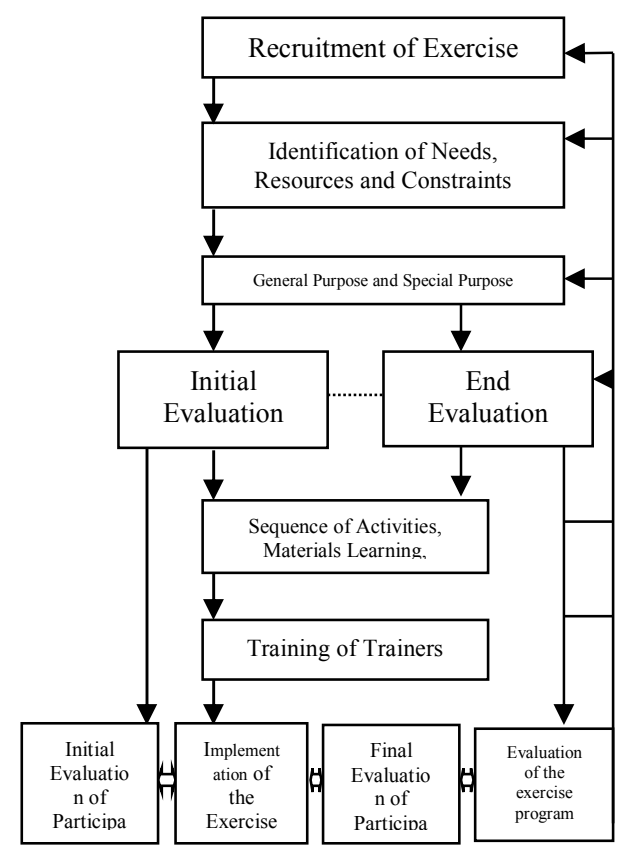

Figure 2. Activity Steps Model of Participatory Exercise

\section{CONCLUSION}

Supervision of the Participatory Training Model has a dimension of training management, so that the training can work well and succeed effectively and efficiently. The training management process begins with analysis, ie needs analysis (need analysis) on things that will become the object of training, then proceed with the design of training programs, which is the step of designing training programs. The next stage is the implementation and implementation, namely the implementation process and Implementation of training programs. Then it ends with an evaluation that is the stage to provide assessment and development analysis. At each stage there will be a feedback process, which aims to control the effectiveness of the implementation and the training process.

Pamong learn to be qualified and professional in order to increase human resources in non-formal education units. To realize the pamong of learning that qualified and professional hence required the competence of comprehending covering aspect of andragogy, pedagogy, personality, social and also professional. A Pamong learning besides mastering competence is also required to have a high spirit and motivation when conducting teaching and learning process in education and training activities, learning, piloting of non formal education program and assessment in order to control the quality and impact of program implementation.

\section{REFERENCES}

[1] Abdul Rahmat dan Christina Catur Widayati. (2016). Perceptual Mapping Leadership in Ethnic Regional Perspective (Studies in Six Ethnic Dominant Gorontalo). International Journal of Economic Perspectives, 10, 2, pp. 171-179.

[2] Bogdan dan Biklen (1982). Job Analysis. Methods, Research, and Applications for Human Resource Management in The New Millennium. London: Sage Publications.

[3] Dadhich and K. T. Bhal, (2008) Ethical Leader Behavior and Leader-MemberExchange as Predictors of Subordinate Behaviors, Journal for Decision Makers, 33, 4.

[4] Daft, Richard L., (2003). Management. Sixth Edition. Ohio: Thomson South-Western.

[5] David, Fred R. (1999). Strategic Management; Concept and Cases. Seventh Edition. New Jersey: Prentice-Hall International, Inc.

[6] Departemen Pendidikan dan Kebudayaan. (1992). Undang-Undang Republik Indonesia dan Peraturan Pemerintah Republik Indonesia. Bagian Proyek Pengembangan Ketenagaan Diklusepora Direktorat Jenderal Pendidikan Luas Sekolah Pemuda, dan Olahraga Departemen Pendidikan dan Kebudayaan. Jakarta

[7] Drucker, Peter F. (1977). An Introductory View of Management. New York: Harper's College Press.

[8] Gibson, Ivancevich, Donnelly, 1996, Organisasi, Perilaku, Struktur, Proses, ( Alih Bahasa Nunuk Adiarni). Jakarta: Binarupa Aksara.

[9] Griffin, Ricky W., and Ronald J. Ebert. (2006). Business. Eighth Edition, International Edition. New Jersey: Prentice-Hall / Pearson.

[10] Laird, Dugan. (1985). Approaches To Training and Development. Second Edition. AddisonWesley Publishing Company

[11] Luanglath, Inpong. (2014). Sample Size Determination for Non-Finite Population. Southeast-Asian Journal of Sciences, 3, 2, pp. $141-152$.

[12] Mello, Jeffrey A. (2002). Strategic Human Resource Management. Cincinnati, Ohio: South-Western College Publishing.

[13] Merzuki, Siti Emalia and A. Latif, Hamrila. (2009). Information Management (IM) for Academic Staff Advancement Programme in 
Higher Institutions. Journal of Technology Management \& Innovation, 4, 1, pp. 94-104.

[14] Miles dan Huberman (1992). Methodology Qualitative. An Introduction. Second Edition. New Jersey: Prentice-Hall, Inc.

[15] Muenjohn, Nuttawuth dan Anona Armstrong. (2007). Transformational Leadership: The influence of Culture on the Leadership Behaviours of Expatriate Manager. International Journal of Business and Information. Centre for International Corporate Governance Research.

[16] Phinney, J. S., Cantu, C. L., \& Kurtz, D. A. (1997). Ethnic and American identity as predictorsof self-esteem among African American, Latino, and White adolescents. Journal of Youthand Adolescence, 26, 2, pp. 165-185.

[17] Robbins, SP. (2014). Organizational Behavior, 9th ed.. Upper Saddle River, New Jersey, 07458: Prentice-Hall Inc.

[18] Robbins, SP. (2005). Teori Pengembangan Organisasi. Alih Bahasa Hadyana. Jakarta: Bumi Aksara.

[19] Rossett, Allison \& W. Arwady, Joseph. (1987). Training Needs Assesment. Educational
Technology Publications Englewood Cliffs, New Jersey 07632

[20] Ruky. AS. (2001). Sistem Manajemen Kinerja: Performance Management System, Panduan Praktis untuk Merancang dan Meraih Kinerja Prima. Jakarta: Gramedia Pustaka Utama

[21] Siagian, Sondang P. (2003). Filsafat Administrasi. Edisi Revisi. Jakarta: Bumi Aksara.

[22] Siagian, SP. (1992). Organisasi, Kepemimpinan dan Perilaku Administrasi. Jakarta: Gunung Agung.

[23] Sudjana, D., (1993), Metoda dan teknik pembelajaran partisipatif, Bandung, Nusantara Press

[24] UNESCO, (1993), Appeal Training Material For Continuing Education Personnel (ATLPCE). Continuing Education: New Polices and Directions. UNESCO Principal Regional Office Asia and the Pacific

[25] Veithzal Rivai,. (2004). Manajemen Sumber Daya Manusia Untuk Perusahaan, Jakarta: Raja Grafindo Persada.

[26] Yueh-Shian Lee dan Weng-Kun Liu, (2012). Leadership Behaviors and Culture Dimension in The Financial Industry. Journal of Applied Finance \& Banking, 2, 15-44. 